\title{
Influence of habitat, trophic ecology and lipids on, and spatial trends of, organochlorine contaminants in Arctic marine invertebrates
}

\author{
Aaron T. Fisk ${ }^{1,8, *}$, Paul F. Hoekstra ${ }^{1,2}$, Jean-Marc Gagnon ${ }^{3}$, Jason Duffe ${ }^{4}$, \\ Ross J. Norstrom ${ }^{4}$, Keith A. Hobson ${ }^{5,6}$, Michael Kwan ${ }^{7}$, Derek C. G. Muir ${ }^{1,2}$ \\ ${ }^{1}$ National Water Research Institute, Environment Canada, Burlington, Ontario L7R 4A6, Canada \\ ${ }^{2}$ Department of Environmental Biology, University of Guelph, Guelph, Ontario N1G 2W1, Canada \\ ${ }^{3}$ Canadian Museum of Nature, PO Box 3443 STN ‘'D', Ottawa, Ontario K1P 6P4, Canada \\ ${ }^{4}$ National Wildlife Research Centre, Environment Canada, Ottawa, Ontario K1A 0H3, Canada \\ ${ }^{5}$ Department of Biology, University of Saskatchewan, Saskatoon, Saskatchewan S7N 0W0, Canada \\ ${ }^{6}$ Prairie and Northern Wildlife Research Center, CWS, Saskatoon, Saskatchewan S7N 0X4, Canada \\ ${ }^{7}$ Nunavik Research Center, Kuujjuaq, Quebec J0M 1C0, Canada \\ ${ }^{8}$ Present address: Warnell School of Forest Resources, University of Georgia, Athens, Georgia 30602-2152, USA
}

\begin{abstract}
Organochlorine contaminants (OCs) and stable isotopes of carbon $\left(\delta^{13} \mathrm{C}\right)$ and nitrogen $\left(\delta^{15} \mathrm{~N}\right)$ were determined in 7 benthic and 7 pelagic marine invertebrate species from the North American Arctic to identify factors influencing OC concentrations. Values of $\delta^{13} \mathrm{C}$ separated benthic (enriched in ${ }^{13} \mathrm{C}$ ) from pelagic species and $\delta^{15} \mathrm{~N}$ values gave a logical approximation of trophic level (TL). With few exceptions, OC concentrations in invertebrates were low (most were $<5 \mathrm{ng} \mathrm{g}^{-1}$ wet wt) relative to the same or similar species in temperate waters and in the range expected for lower TL Arctic organisms. Polychlorinated biphenyls (PCBs) were the predominant OC group and lower chlorinated $\mathrm{PCB}$ congeners and hexachlorocyclohexane $(\mathrm{HCH})$ isomers were the most common individual OCs in most species. Relatively higher levels of PCBs and high proportions of highly chlorinated PCB congeners were found in a small number of the pelecypod samples (Mytilus edulis and Mya truncata), suggesting that local harbors and communities can be point sources of PCBs in the Arctic. The OC concentrations (wet wt) varied by up to 2 orders of magnitude among species and were more variable among the benthic invertebrates. Lipid content, $\delta^{13} \mathrm{C}$ and $\delta^{15} \mathrm{~N}$ were significant variables related to OC concentration, but differences among species remained after accounting for these variables. Scavenging, high TL, high lipid content and local point sources can all contribute to higher $\mathrm{OC}$ concentrations in Arctic marine invertebrates.
\end{abstract}

KEY WORDS: Stable isotopes $\cdot$ Carbon-13 $\cdot$ Nitrogen-15 $\cdot$ Zooplankton $\cdot$ Benthic $\cdot$ Pelagic

\section{INTRODUCTION}

Aquatic invertebrates provide a link between primary production and upper trophic-level (TL) marine organisms such as fish, birds and mammals (Valiela 1995), although there are a large number of species that are scavengers and parasites. Invertebrates associated with the water column are commonly referred to as pelagic or zooplanktons, whereas those associated with sediment are referred to as benthic organisms. Many invertebrates spend time or feed in more than one area and others spend time in different areas during different stages of development (Valiela 1995). The behavior and feeding ecology of invertebrates play an important role in the cycling of carbon and other important elements in aquatic food webs (Hobson et al. 2002).

Persistent organochlorine contaminants (OCs) move through aquatic food webs in a similar manner to car- 
bon (Wallberg \& Andersson 2000). Therefore, aquatic invertebrates are likely to play an important role in the dynamics of contaminants in aquatic food webs. Also, the level of OC exposure by upper TL organisms will depend on their choice of species as prey (Muir et al. 1995).

Characteristics of Arctic marine food webs, in particular high lipid levels, which are adaptations to the cyclic annual productivity, give rise to higher than expected OC concentrations, despite low levels in the abiotic Arctic environment (de March et al. 1998). While concentrations of many OCs (e.g. hexachlorocyclohexane $[\mathrm{HCH}]$, chlordanes and polychlorinated biphenyl [PCB] congeners) are declining quite rapidly in Arctic air (half-lives of 5 to 9 yr for chlordane-related compounds; Bidleman et al. 2002), there have been much slower declines in biota (de Wit et al. 2003). This discontinuity between temporal trends of OCs in the abiotic and biotic components of the Arctic illustrates the need to improve our understanding of processes influencing the movement of OCs through Arctic marine food webs (Braune et al. 2001a, de Wit et al. 2003). Forecasted changes to climate, ice cover and ocean currents in the Arctic are likely to result in alterations to food webs and carbon cycling, and subsequently tropho-dynamics and fate of contaminants (Macdonald 2003). Despite this, factors that govern OC levels and patterns in aquatic invertebrates are largely unexplored, particularly for the Arctic marine ecosystem and benthic invertebrates. Recent studies by Borgå et al. $(2002 \mathrm{a}, \mathrm{b}, \mathrm{c})$ have found that size, diet, habitat and geography can all influence OC levels in pelagic and sympagic Arctic marine zooplankton. Hargrave et al. $(1992,2000)$ found that season and lipid content played important roles in OC concentrations in Arctic marine zooplankton. Additionally, OC concentrations in Arctic herbivorous copepods were generally found to be related to water OC concentrations, but dietary accumulation, chemical-physical characteristics of the chemical and seasonal changes in the biological characteristics of the organisms were noted as important variables (Fisk et al. 2001a, Hoekstra et al. 2002a).

The objectives of this work were to identify variables that influence patterns and concentrations as well as the spatial trends of OCs in Arctic marine invertebrates. To accomplish this, we combined recently generated OC data for a number of Arctic marine invertebrate species. These include benthic and pelagic species that cover a number of TLs and feeding strategies (Hobson et al. 2002); thus, providing an opportunity to examine the influence of these biological variables on concentrations and relative proportions of OCs in Arctic marine invertebrates. Measurements of stable isotopes of carbon and nitrogen were also made on most samples; thereby, providing a means to assess the effects of carbon source and trophic position on OC concentrations. The ratio of the heavier to lighter stable isotopes of nitrogen $\left({ }^{15} \mathrm{~N} /{ }^{14} \mathrm{~N}\right)$, expressed as $\delta^{15} \mathrm{~N}$, generally increases with trophic position in aquatic food chains (Michener \& Schell 1994, Hobson et al. 1995). Stable carbon isotope ratios $\left({ }^{13} \mathrm{C} /{ }^{12} \mathrm{C}\right)$, expressed as $\delta^{13} \mathrm{C}$, show less enrichment with trophic transfer, but can be useful in evaluating sources of primary production in marine

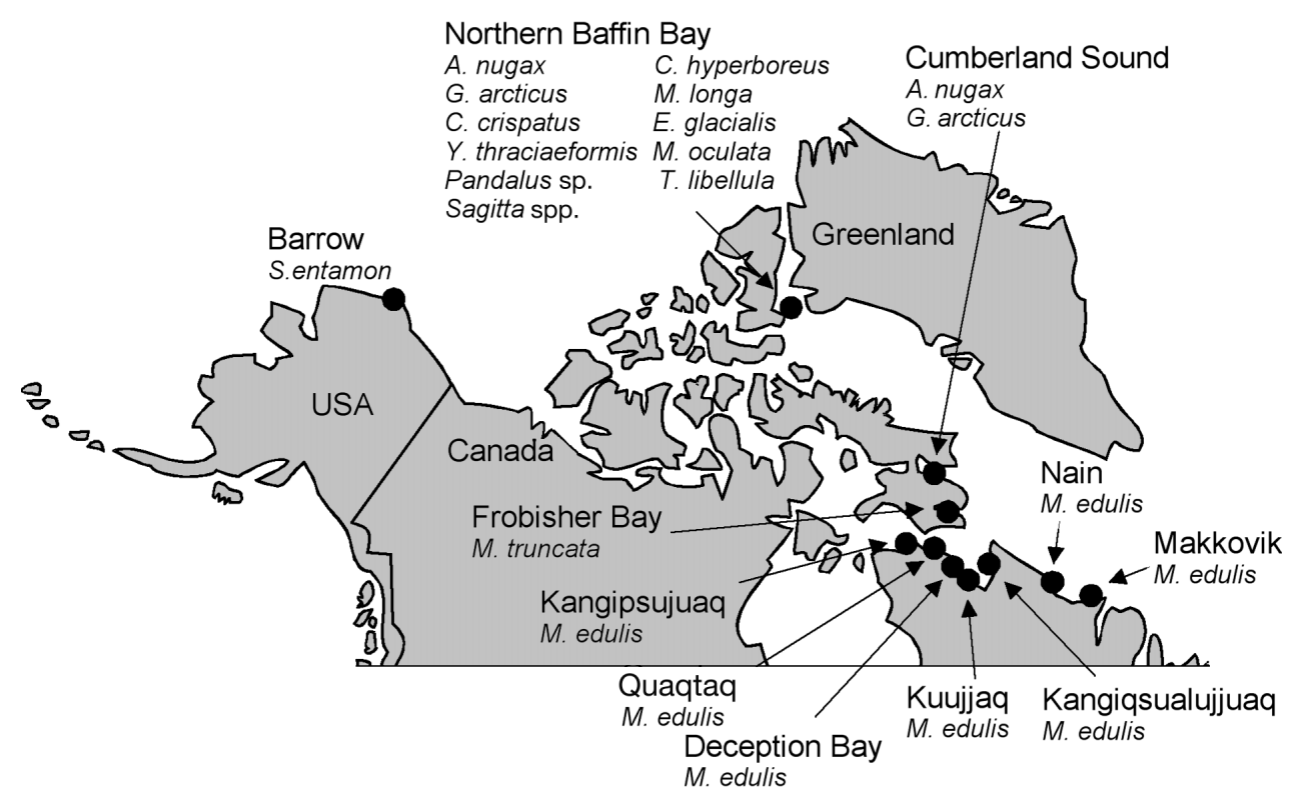

Fig. 1. Sampling region of invertebrate species collected at each sampling site for organochlorine contaminants analysis 
systems as well as general patterns of inshore/benthic versus offshore/pelagic feeding preferences (Hobson \& Welch 1992, Lawson \& Hobson 2000).

\section{MATERIALS AND METHODS}

For this study, invertebrates were classified as 'pelagic' or 'benthic' based on the method of collection. Pelagic invertebrates or zooplankton were collected with zooplankton nets pulled through the water col- umn. Benthic species were collected from the ocean floor by traps, lines and sediment box cores or by hand near or onshore.

Sample collection. A number of invertebrate species were collected from numerous locations throughout the Canadian and Alaskan Arctic as parts of larger studies (Fig. 1, Table 1). All zooplankton samples (referred to as pelagic) were collected between May and July in 1998 in Northern Baffin Bay from approximately 76 to $78^{\circ} \mathrm{N}$. Zooplankton samples were collected at various stations within an approximate area

Table 1. Biological characteristics of Arctic invertebrates analyzed for organochlorine contaminants (OCs). Benthic (box cores, baited traps, or by hand) and pelagic (zooplankton net tows) designations refer to collection method used. na: not available

\begin{tabular}{|c|c|c|c|c|c|c|c|c|}
\hline $\begin{array}{l}\text { Group } \\
\text { Species }\end{array}$ & $\begin{array}{l}\text { Common } \\
\text { name }\end{array}$ & $\begin{array}{l}\text { Feeding } \\
\text { mode }^{\mathrm{a}}\end{array}$ & Habitat $^{\mathrm{b}}$ & $\mathrm{n}^{\mathrm{c}}$ & $\delta^{13} \mathrm{C}^{\mathrm{d}}$ & $\begin{array}{l}\text { Relative } \\
\text { carbon } \\
\text { source }\end{array}$ & $\delta^{15} \mathrm{~N}^{\mathrm{d}}$ & $\begin{array}{c}\text { Relative } \\
\text { trophic }^{\mathrm{f}} \\
\text { level }^{\mathrm{f}}\end{array}$ \\
\hline \multicolumn{9}{|l|}{ Benthic } \\
\hline \multicolumn{9}{|l|}{ Amphipod } \\
\hline Anonyx nugax & None & $\mathrm{SC}$ & SPB-SB & 6 (pool) & $-19.3 \pm 0.5$ & 1.14 & $13.5 \pm 0.8$ & 3.4 \\
\hline \multicolumn{9}{|l|}{ Echinodermata } \\
\hline Gorgonocephalus arcticus & Basket starfish & SPF-DF & SB-SBS & 6 (ind.) & $-21.5 \pm 0.8$ & 1.20 & $13.0 \pm 0.3$ & 3.1 \\
\hline Ctenodiscus crispatus & Mud starfish & DF & SB-EB & 2 (ind.) & $-17.8 /-18.3$ & 1.40 & $12.4 / 13.2$ & 3.3 \\
\hline \multicolumn{9}{|l|}{ Bivalve } \\
\hline Yoldia thraciaeformis & Yoldia clam & SPF & EB & 1 (ind.) & -19.1 & 1.19 & 7.8 & 2.0 \\
\hline Mytilus edulis & Blue mussel & SPF & SBS & na & na & na & na & $(2.0)$ \\
\hline Mya truncata & Soft-shell clam & SPF & EB-SBS & na & na & na & na & $(2.0)$ \\
\hline \multicolumn{9}{|l|}{ Isopod } \\
\hline Saduria entamon & Sea cockroach & $\mathrm{DF} / \mathrm{O}$ & SB-EB & 3 (ind.) & $-20.6 \pm 0.3$ & 1.22 & $14.3 \pm 0.5$ & 3.1 \\
\hline \multicolumn{9}{|l|}{ Pelagic } \\
\hline \multicolumn{9}{|l|}{ Copepod } \\
\hline Calanus hyperboreus & None & SFF-FF ? & PL & 20 (pool) & $-23.6 \pm 0.2$ & 1.00 & $7.7 \pm 0.2$ & 2.0 \\
\hline Metridia longa & None & PR-SFF ? & PL & 3 (pool) & $-23.4 \pm 0.3$ & 1.01 & $9.5 \pm 0.3$ & 2.5 \\
\hline Euchaeta glacialis & None & PR & PL & 3 (pool) & $-24.4 \pm 0.1$ & 0.97 & $11.7 \pm 0.1$ & 3.0 \\
\hline \multicolumn{9}{|l|}{ Mysidacea } \\
\hline Mysis oculata & Mysid & DF-PR & SPB-SB & 7 (pool) & $-22.7 \pm 0.2$ & 1.03 & $10.6 \pm 0.1$ & 2.7 \\
\hline \multicolumn{9}{|l|}{ Amphipod } \\
\hline Themisto libellula & None & $\mathrm{PR}$ & PL & 4 (pool) & $-23.2 \pm 0.1$ & 1.03 & $10.0 \pm 0.1$ & 2.5 \\
\hline \multicolumn{9}{|l|}{ Decapod } \\
\hline Pandalus sp. & Shrimp & DF-PR & SPB-SB & 2 (ind.) & $-17.8 /-18.3$ & 1.12 & $12.7 / 13.8$ & 3.4 \\
\hline \multicolumn{9}{|l|}{ Miscellaneous } \\
\hline Sagitta spp. & Arrow worm & PR & PL & 6 (pool) & $-23.8 \pm 0.1$ & 0.99 & $10.0 \pm 0.4$ & 2.7 \\
\hline \multicolumn{9}{|c|}{$\begin{array}{l}\text { aFeeding mode (from Hobson et al. } 2002 \text { except for } M \text {. edulis and S. entamon). FF: filter feeder; SFF: selective-filter feeder; } \\
\text { SPF: suspension feeder; PR: predator; SC: scavenger; and DF: detritus. S. entomon have been described as omnivorous } \\
\text { feeders (O) (Khlebovich 1997) }\end{array}$} \\
\hline \multicolumn{9}{|c|}{$\begin{array}{l}\text { b Habitat (from Hobson et al. } 2002 \text { except for } M \text {. edulis and S. entamon). PL: plankton; SPB: supra benthic; SB: surface benthic; } \\
\text { EB: endobenthic; and SBS: surface-benthic-sessile }\end{array}$} \\
\hline \multicolumn{9}{|c|}{ 'Number of samples (n) used to determine stable isotope values } \\
\hline \multirow{2}{*}{\multicolumn{9}{|c|}{$\begin{array}{l}{ }^{\mathrm{d}} \text { Values are mean } \pm 1 \mathrm{SE} \\
\text { e Relative carbon source }=\delta^{13} \mathrm{C}_{\text {invertebrate }} / \delta^{13} \mathrm{C}_{C .} \text {. hyperboreus, where } \delta^{13} \mathrm{C}_{\text {invert }} \text { is the organism in question and } \delta^{13} \mathrm{C}_{C . \text { hyperboreus }} \text { repre- } \\
\text { sents the values found in } C \text {. hyperboreus. C. hyperboreus is a pelagic-filter feeding herbivore that has a pelagic } \delta^{13} \mathrm{C} \text { signal, } \\
\text { values close to } 1 \text { or below are pelagic and values greater than } 1 \text { represent a more benthic carbon source }\end{array}$}} \\
\hline & & & & & & & & \\
\hline \multicolumn{9}{|c|}{$\begin{array}{l}\text { f Trophic level was determined relative to the calanoid copepod C. hyperboreus, which we assumed occupied trophic level } \\
\text { (TL) } 2 \text { (i.e. a primary herbivore) (Hobson et al. 2002). Using the additional assumption that isotopic enrichment was constant } \\
\text { among trophic levels and of the order of } 3.8 \% \text { (Hobson \& Welch 1992), we calculated the relative trophic level of consumers } \\
\text { according to: TL }=2+\left(\delta^{15} \mathrm{~N}_{\text {invertbrate }}-\delta^{15} \mathrm{~N}_{C \text {. hyperboreus }}\right) / 3.8 \text {. S. entamon trophic position was based on the same equation, } \\
\text { but using } \delta^{15} \mathrm{~N} \text { values for calanoid copepods collected in Barrow (Hoekstra et al. 2002b). Stable isotope values were not } \\
\text { determined for } M \text {. edulis or } M \text {. truncata samples, but as suspension feeders their trophic position were assumed to be } 2.0\end{array}$} \\
\hline
\end{tabular}


of $30 \mathrm{~km}^{2}$ by vertical tows of zooplankton nets $\left(1 \mathrm{~m}^{2}\right.$, 200 or $520 \mu \mathrm{m}$ mesh), generally from bottom-tosurface, from the deck of the Canadian Coast Guard vessel 'Pierre Radisson'. Samples from the nets were immediately transferred to clean seawater. Zooplankton were sorted into species shortly after collection $(<2 \mathrm{~h})$, placed in plastic cyro-vials and frozen until analyzed for stable isotopes (SI) and OCs. The number of individuals per sample varied between stations and species, but individuals were not counted. Samples from each station (1 sample per station per species) were split for SI and OC analysis. SI was performed on each sample from a station. Due to small sample sizes and low OC concentrations, samples were combined for contaminant analysis. Samples that were combined into 1 sample for OC analysis came from stations that were geographically close (within $\sim 10 \mathrm{~km}$ ) and collected within 3 to $4 \mathrm{~d}$ of each other. Stable isotope for these contaminants samples reflected the values of each of the individual samples that were combined.

Benthic invertebrates were collected by a number of methods. Mya truncata samples were collected between May and July 1993 in Iqaluit harbor by hand. Mytilus edulis samples were collected in July 1998 by hand at 7 locations in northern Quebec and Labrador (Fig. 1). Saduria entamon samples were collected by hand on the shores of northern Alaska near Barrow in September 1998 following a storm. Anonyx nugax and Gorgonocephalus articus were collected in April 1999 in Cumberland Sound and in July 1998 in Northern Baffin Bay using baited traps or long-line fishing gear. Yoldia thraciaeformis was collected from a box core sample in Northern Baffin Bay in July 1998. All samples were frozen shortly after collection and subdivided later for OC and SI analysis.

Extraction, cleanup and analysis of samples for organochlorine contaminants. Analysis of PCBs and OC pesticides in invertebrate samples was performed in 2 laboratories: National Water Research Institute (NWRI) Burlington and the Freshwater Institute (FWI), Winnipeg. Both labs were involved in interlaboratory calibration exercises as part of the Canadian 'Northern Contaminants Program' when the analyses for this study were conducted (Stokker 2000, 2001). The methods used to extract PCBs and OC pesticides followed the routine procedures with slight modifications. Benthic samples collected in Northern Baffin Bay, Cumberland Sound and Iqaluit harbor and all zooplankton samples were analyzed at FWI. Samples were freeze dried, spiked with an internal standard $\left(2,2^{\prime}, 3,4,4^{\prime}\right.$, 5, 6, 6'-octachlorobiphenyl [PCB 204] and octachloronaphthalene) and extracted with dichloromethane (DCM)/hexane (1:1) using a Dionex ASE 200 accelerated solvent extractor (Dionex Canada). All other invertebrate samples were analyzed at NWRI (Saduria entamon and Mytilus edulis). Wet samples were spiked with the same internal standard, homogenized with $\mathrm{Na}_{2} \mathrm{SO}_{4}$ and Soxhlet-extracted with DCM for $16 \mathrm{~h}$ (Hoekstra et al. 2002a).

Following extraction, a fraction of the extract was used to determine lipids gravimetrically. Lipids were removed from the sample by gel permeation chromatography (GPC). The lipid-free eluate, containing the OCs, was evaporated to $1 \mathrm{ml}$ and applied to a Florisil (8 g, 1.2\% deactivated, all zooplankton and benthic samples except Saduria entamon and Mytilus edulis) or silica (8 g, 100\%-activated, S. entamon and M. edulis only) column. For the Florisil cleanup, OCs were recovered by consecutive elution with $35 \mathrm{ml}$ hexane, $38 \mathrm{ml}$ 85:15 hexane:DCM and $50 \mathrm{ml}$ DCM: hexane. (See Fisk et al. [2001a] for Florisil elution patterns of OCs). For the silica gel cleanup, OCs were separated into 2 fractions: Fraction 1 (eluted with $65 \mathrm{ml}$ hexane) containing $100 \%$ of the PCB congeners, along with chlorobenzene isomers, and $o, p^{\prime}$ - and $p, p$-DDE, and Fraction 2 (90 ml DCM:hexane) containing chlordane-related compounds, $\mathrm{HCH}$ isomers, and other DDT-related compounds. All fractions were rotary evaporated, transferred to 2,2',4-trimethylpentane and were evaporated to approximately $100 \mu$ l. Aldrin was added as a volume corrector for all samples except $S$. entamon and $M$. edulis, in which the hexachlorobiphenyl CB-166 was used as a performance standard.

Samples $(100 \mu \mathrm{l})$ analysis at the FWI and NWRI were similar except for the type of gas chromatograph (GC). Samples analyzed at the FWI used Varian (Palo Alto) 3600 GC and samples analyzed at NWRI used a Hewlett-Packard (Wilmington) 5890 GC. At both FWI and NWRI, the GC was equipped with a $60 \mathrm{~m} \times$ $0.25 \mathrm{~mm}$ DB-5 column ( $\mathrm{J} \& \mathrm{~W}$ Scientific) and a ${ }^{63} \mathrm{Ni}-$ electron capture detector (ECD), the carrier gas was $\mathrm{H}_{2}$, and $\mathrm{N}_{2}$ was used as the make-up gas for the ECD. External standards were run after every 6 samples. Standards recoveries of PCB 30 and OCN for all samples were $75.6 \pm 2.3($ mean $\pm 1 \mathrm{SE}$ ) and $76.5 \pm 2.1$, respectively. Concentrations were not corrected for recoveries. Standard reference materials (NIST 1588a cod liver oil) were run by all labs and results were within $20 \%$ of certified values. Both labs achieved results for major OC pesticides and $\mathrm{PCB}$ congeners within $30 \%$ of consensus values as part of NCP interlaboratory exercises (Stokker 2000, 2001).

Stable isotope analysis. Stable isotope abundance was determined in all samples except Mya truncata and Mytilus edulis samples. Prior to stable isotope analyses, all tissue samples were washed in distilled water and then freeze dried, powdered and treated with a 2:1 chloroform:methanol solution to remove lipids. Samples were then dried under a fume hood, soaked in $0.1 \mathrm{~N} \mathrm{HCl}$ to remove carbonates and allowed 
to dry without rinsing. Stable carbon and nitrogen isotope assays were performed on $1 \mathrm{mg}$ subsamples of homogenized materials by loading into tin cups and combusting at $1800^{\circ} \mathrm{C}$ in a Robo-Prep elemental analyzer. Resultant $\mathrm{CO}_{2}$ and $\mathrm{N}_{2}$ gases were then analyzed using an interfaced Europa 20:20 continuous-flow isotope ratio mass spectrometer (CFIRMS) with every 5 unknowns separated by 2 laboratory standards. Stable isotope abundances were expressed in $\delta$ notation as the deviation from standards in parts per thousand $(\%)$ according to the following equation:

$$
\delta \mathrm{X}=\left[\left(\mathrm{R}_{\text {sample }} / \mathrm{R}_{\text {standard }}\right)-1\right] \times 1000
$$

where $\mathrm{X}$ is ${ }^{13} \mathrm{C}$ or ${ }^{15} \mathrm{~N}$ and $\mathrm{R}$ is the corresponding ratio ${ }^{13} \mathrm{C} /{ }^{12} \mathrm{C}$ or ${ }^{15} \mathrm{~N} /{ }^{14} \mathrm{~N}$. The $\mathrm{R}_{\text {standard }}$ values were based on the PeeDee Belemnite (PDB) for ${ }^{13} \mathrm{C}$ and atmospheric $\mathrm{N}_{2}$ (AIR) for ${ }^{15} \mathrm{~N}$. Replicate measurements of internal laboratory standards (albumen) indicate measurement errors of $\pm 0.3 \%$ for stable nitrogen isotope measurements.

TL was determined relative to the calanoid copepod Calanus hyperboreus, which we assumed occupied TL 2 (i.e. a primary herbivore) (Hobson et al. 2002). Using the additional assumption that isotopic enrichment was constant among TLs and of the order of $3.8 \%$ (Hobson \& Welch 1992), we calculated the relative TL according to:

$\mathrm{TL}_{\text {invertebrate }}=2+\left(\delta^{15} \mathrm{~N}_{\text {invertbrate }}-\delta^{15} \mathrm{~N}_{\text {C. hyperboreus }}\right) / 3.8$

Saduria entamon trophic position was based on the same equation but using $\delta^{15} \mathrm{~N}$ values for calanoid copepods collected in Barrow (Hoekstra et al. 2002b). Stable isotope values were not determined for Mytilus edulis or Mya truncata samples, but as suspension feeders their trophic position were assumed to be 2.0.

Statistical analysis. Concentration data were natural $\log$ transformed prior to statistical analysis to reduce skewness. Variation in the contaminant data was examined at the $\delta O C$ group level. $\Sigma O C$ were used because of the limited number of samples $(n=88)$ available for statistical analysis. Individual compounds that were included in each of the $\Sigma O C$ groups are summarized in Table 2. Data for Yoldia thraciaeformis and juvenile Themisto libellula were not included in the statistical analysis because they were single samples. Stable isotope values were not available for Mytilus edulis and Mya truncate; both suspension-feeding mollusks. To generate expected $\delta^{15} \mathrm{~N}$ and $\delta^{13} \mathrm{C}$ values for these samples, a random number was generated between the values for the $Y$. thraciaeformis, a filterfeeding clam that was found to be feeding at a TL of 2 based on its $\delta^{15} \mathrm{~N}$ value and had a benthic $\delta^{13} \mathrm{C}$ signature $\pm 1 \mathrm{SE}$ generated from all samples from the data set (Table 1). A study of stable isotope values in Northern Baffin Bay that includes a larger number of sam- ples found that most filter-feeding mussels were at a TL of 2 (Hobson et al. 2002). Although SI values have been shown to vary geographically in the Arctic (Schell et al. 1998), all but 1 species, Saduria entamon, were collected in the eastern Canadian Arctic.

To assess the influence of $\delta^{13} \mathrm{C}, \delta^{15} \mathrm{~N}$ and lipid on OC concentrations, a general linear model (GLM) with the following equation was used:

$$
\log [\Sigma \mathrm{OC}]=\delta+\delta^{13} \mathrm{C}+\delta^{15} \mathrm{~N}+\text { Lipid }+\varepsilon
$$

where $\Sigma O C$ represents each of the OC groups in turn ( $\Sigma$ PCB, $\Sigma \mathrm{DDT}, \Sigma \mathrm{CHLOR}, \Sigma \mathrm{ClBz}$ and $\Sigma \mathrm{HCH}$ ), $\delta$ is a constant and $\varepsilon$ is an error term. The significance of each variable was then assessed with Type III SS, which removes the variance associated with the other variables.

A second GLM was run to determine whether differences in $\mathrm{OC}$ concentrations between species were significant after removing the influence of $\delta^{13} \mathrm{C}, \delta^{15} \mathrm{~N}$ and lipid using the model:

$\log [\Sigma \mathrm{OC}]=\delta+$ Species $+\delta^{13} \mathrm{C}+\delta^{15} \mathrm{~N}+$ Lipid $+\varepsilon$

An a posteriori Scheffe's test was performed for all OC groups on the species variable to assess the relative levels between invertebrate species. Due to low sample sizes for a number of species, the Scheffe's test was chosen because it reduces Type I errors, but has a higher rate of Type II errors, making this test relatively more conservative than other statistical comparisons. All GLM and a posteriori analyses were performed using SAS Version 8.0 (Cary).

\section{RESULTS}

\section{Stable isotopes}

Benthic organisms, as defined by collection methods, were enriched in ${ }^{13} \mathrm{C}$ compared to organisms defined as pelagic (Table 1). Values of $\delta^{13} \mathrm{C}$ in the pelagic invertebrates were consistent among species with a slightly ${ }^{13} \mathrm{C}$-enriched (i.e. more benthic) value in Pandalus sp. Values of $\delta^{13} \mathrm{C}$ were also similar among benthic invertebrates. Trophic positions determined from $\delta^{15} \mathrm{~N}$ values ranged nearly 1.5 TLs, assuming that a change of $3.8 \%$ in $\delta^{15} \mathrm{~N}$ represents $1 \mathrm{TL}$ (Hobson et al. 1995, 2002), with the highest values in the scavenging and detritus-feeding benthic organisms and the predatory pelagic invertebrate Pandalus sp. (Table 1). The single species of suspension-feeding benthic organism, Yoldia thraciaeformis, for which there were stable isotope values, was at the same TL as Calanus hyperboreus. The TLs of the pelagic invertebrates were generally 0.5 to 1.4 TLs higher than the herbivorous copepod C. hyperboreus. 
Table 2. Water and lipid content (\%) and organochlorine wet weight concentrations (ng g ${ }^{-1}$, mean \pm 1 SE except for species/ locations with 2 or fewer samples which report the values) in Arctic marine invertebrates. na: not available

\begin{tabular}{|c|c|c|c|c|c|c|c|c|c|}
\hline $\begin{array}{l}\text { Group } \\
\text { Species }\end{array}$ & $\begin{array}{l}\text { Sampling } \\
\text { region }^{\mathrm{a}}\end{array}$ & $\mathrm{n}^{\mathrm{b}}$ & $\begin{array}{c}\text { Water } \\
\text { content }\end{array}$ & $\begin{array}{l}\text { Lipid } \\
\text { content }\end{array}$ & $\Sigma \mathrm{ClBz}^{\mathrm{c}}$ & $\Sigma \mathrm{HCH}^{\mathrm{d}}$ & $\Sigma \mathrm{CHLOR}^{\mathrm{e}}$ & $\Sigma \mathrm{DDT}^{\mathrm{f}}$ & $\Sigma \mathrm{PCB}^{\mathrm{g}}$ \\
\hline \multicolumn{10}{|l|}{ Benthic } \\
\hline \multicolumn{10}{|l|}{ Amphipod } \\
\hline A. nugax & $\begin{array}{l}\text { NBB } \\
\text { CS }\end{array}$ & $\begin{array}{l}5 \text { (pool) } \\
1 \text { (pool) }\end{array}$ & $\begin{array}{c}75.9 \pm 1.5 \\
64.8\end{array}$ & $\begin{array}{c}2.5 \pm 0.31 \\
4.2\end{array}$ & $\begin{array}{c}2.2 \pm 0.57 \\
5.7\end{array}$ & $\begin{array}{c}10.0 \pm 4.7 \\
26.2\end{array}$ & $\begin{array}{l}5.0 \pm 0.32 \\
20.5\end{array}$ & $\begin{array}{c}5.0 \pm 0.29 \\
19.8\end{array}$ & $\begin{array}{c}16.5 \pm 4.0 \\
54.6\end{array}$ \\
\hline \multicolumn{10}{|l|}{ Echinodermata } \\
\hline G. arcticus & $\begin{array}{c}\text { NBB } \\
\text { CS }\end{array}$ & $\begin{array}{l}3 \text { (ind.) } \\
3 \text { (ind.) }\end{array}$ & $\begin{array}{l}73.9 \pm 1.7 \\
72.1 \pm 0.1\end{array}$ & $\begin{array}{r}8.5 \pm 1.2 \\
11.4 \pm 1.3\end{array}$ & $\begin{array}{r}0.64 \pm 0.12 \\
2.0 \pm 0.30\end{array}$ & $\begin{array}{c}3.7 \pm 1.4 \\
13.5 \pm 0.94\end{array}$ & $\begin{array}{l}26.3 \pm 6.9 \\
48.5 \pm 5.8\end{array}$ & $\begin{array}{l}25.5 \pm 7.5 \\
27.1 \pm 4.8\end{array}$ & $\begin{array}{l}28.1 \pm 9.6 \\
31.6 \pm 4.1\end{array}$ \\
\hline C. crispatus & NBB & 2 (ind.) & $\begin{array}{l}65.3 \\
71.9\end{array}$ & $\begin{array}{l}1.4 \\
1.8\end{array}$ & $\begin{array}{l}0.21 \\
0.12\end{array}$ & $\begin{array}{l}0.04 \\
0.01\end{array}$ & $\begin{array}{l}0.03 \\
0.02\end{array}$ & $\begin{array}{l}0.08 \\
0.08\end{array}$ & $\begin{array}{l}2.0 \\
2.2\end{array}$ \\
\hline \multicolumn{10}{|l|}{ Bivalve } \\
\hline Y. thraciaeformis & NBB & 1 (pool) & 81.0 & 2.3 & 0.22 & 0.04 & 0.07 & 0.33 & 3.4 \\
\hline M. edulis & $\begin{array}{l}\text { Quaqtaq } \\
\text { Kuujjaaq } \\
\text { angipsujuaq } \\
\text { giqsualujjuaq } \\
\text { Makkovik } \\
\text { Nain }\end{array}$ & $\begin{array}{l}2 \text { (pool) } \\
2 \text { (pool) } \\
2 \text { (pool) } \\
2 \text { (pool) } \\
3 \text { (pool) } \\
2 \text { (pool) }\end{array}$ & $\begin{array}{l}\text { na } \\
\text { na } \\
\text { na } \\
\text { na } \\
\text { na } \\
\text { na }\end{array}$ & $\begin{array}{c}4.6 \\
5.3 \\
2.8 \\
3.1 \\
4.2 \\
5.3 \\
1.4 \\
2.6 \\
2.2 \pm 0.49 \\
2.5 \\
2.5\end{array}$ & $\begin{array}{c}0.49 \\
0.65 \\
1.8 \\
0.43 \\
0.63 \\
0.64 \\
0.20 \\
0.39 \\
2.5 \pm 0.76 \\
2.1 \\
2.1\end{array}$ & $\begin{array}{c}3.1 \\
2.5 \\
1.7 \\
1.1 \\
2.9 \\
2.9 \\
0.60 \\
1.6 \\
1.9 \pm 0.98 \\
1.3 \\
2.1\end{array}$ & $\begin{array}{c}1.2 \\
1.4 \\
1.4 \\
0.56 \\
1.8 \\
1.8 \\
0.44 \\
1.1 \\
9.3 \pm 5.5 \\
2.4 \\
11.8\end{array}$ & $\begin{array}{c}0.78 \\
0.59 \\
0.72 \\
0.18 \\
0.71 \\
0.64 \\
0.09 \\
0.28 \\
1.8 \pm 1.3 \\
0.80 \\
2.1\end{array}$ & $\begin{array}{c}21.0 \\
37.0 \\
84.9 \\
6.6 \\
12.7 \\
15.0 \\
3.2 \\
10.9 \\
5.8 \pm 1.4 \\
8.9 \\
5.3\end{array}$ \\
\hline Deception Bay & & 3 (pool) & na & $1.6 \pm 0.10$ & $1.2 \pm 0.12$ & $0.61 \pm 0.17$ & $2.2 \pm 0.98$ & $0.33 \pm 0.18$ & $3.7 \pm 0.69$ \\
\hline All samples & & 16 (pool) & & $2.9 \pm 0.33$ & $1.3 \pm 0.24$ & $1.7 \pm 0.27$ & $3.65 \pm 1.3$ & $0.83 \pm 0.27$ & $14.6 \pm 5.2$ \\
\hline \multicolumn{10}{|l|}{ Isopod } \\
\hline S. entamon & Barrow & 3 (ind.) & na & $2.1 \pm 0.4$ & $0.36 \pm 0.04$ & $1.7 \pm 0.3$ & $0.61 \pm 0.05$ & $0.50 \pm 0.07$ & $3.1 \pm 0.16$ \\
\hline \multicolumn{10}{|l|}{ Pelagic } \\
\hline \multicolumn{10}{|l|}{ Copepod } \\
\hline C. hyperboreus & NBB & 20 (pool) & $83.0 \pm 1.2$ & $6.3 \pm 0.70$ & $0.43 \pm 0.05$ & $2.5 \pm 0.79$ & $0.85 \pm 0.19$ & $0.84 \pm 0.15$ & $5.1 \pm 0.63$ \\
\hline M. longa & NBB & 3 (pool) & $88.1 \pm 0.09$ & $2.1 \pm 0.12$ & $0.32 \pm 0.09$ & $0.78 \pm 0.11$ & $1.3 \pm 0.12$ & $1.8 \pm 0.27$ & $7.6 \pm 1.9$ \\
\hline E. glacialis & NBB & 3 (pool) & $82.4 \pm 0.26$ & $5.4 \pm 0.33$ & $0.59 \pm 0.03$ & $1.3 \pm 0.11$ & $2.8 \pm 0.11$ & $2.5 \pm 0.12$ & $6.0 \pm 0.04$ \\
\hline \multicolumn{10}{|l|}{ Mysidacea } \\
\hline M. oculata & NBB & 7 (pool) & $82.0 \pm 0.75$ & $5.0 \pm 0.53$ & $0.35 \pm 0.05$ & $0.58 \pm 0.18$ & $0.73 \pm 0.18$ & $1.4 \pm 0.11$ & $5.8 \pm 0.46$ \\
\hline \multicolumn{10}{|l|}{ Amphipod } \\
\hline T. libellula ('adult') & ) NBB & 4 (pool) & $84.2 \pm 1.1$ & $2.2 \pm 0.40$ & $0.43 \pm 0.04$ & $1.7 \pm 0.25$ & $3.8 \pm 0.45$ & $3.1 \pm 0.53$ & $8.8 \pm 1.3$ \\
\hline T. libellula ('juv') & NBB & 1 (pool) & 85.4 & 3.1 & 0.29 & 0.81 & 0.90 & 0.55 & 3.2 \\
\hline \multicolumn{10}{|l|}{ Decapoda } \\
\hline Pandalus sp. & NBB & 2 (ind.) & $\begin{array}{l}73.9 \\
73.7\end{array}$ & $\begin{array}{l}7.0 \\
2.8\end{array}$ & $\begin{array}{l}0.51 \\
0.78\end{array}$ & $\begin{array}{l}1.24 \\
1.98\end{array}$ & $\begin{array}{l}1.96 \\
1.34\end{array}$ & $\begin{array}{l}1.47 \\
1.12\end{array}$ & $\begin{array}{l}26.0 \\
33.7\end{array}$ \\
\hline \multicolumn{10}{|l|}{ Miscellaneous } \\
\hline Sagitta spp. & NBB & 6 (pool) & $90.0 \pm 0.37$ & $2.1 \pm 0.30$ & $0.31 \pm 0.16$ & $0.23 \pm 0.06$ & $0.33 \pm 0.09$ & $0.36 \pm 0.04$ & $2.2 \pm 0.25$ \\
\hline $\begin{array}{l}{ }^{\mathrm{a}} \text { For sampling region } \\
{ }^{\mathrm{b}} \text { Samples were either } \\
{ }^{\mathrm{c}} \Sigma \mathrm{ClBz} \text { (chlorobenzen } \\
{ }^{\mathrm{d}} \Sigma \mathrm{HCH} \text { (hexachlorocy } \\
{ }^{\mathrm{e}} \Sigma \mathrm{CHLOR} \text { (chlordanes } \\
\text { and oxychlordane } \\
{ }^{\mathrm{f}} \Sigma \mathrm{DDT}=\text { sum of } p, p^{\prime}-\mathrm{D} \\
{ }^{\mathrm{g}} \Sigma \mathrm{PCB}=\text { sum of conge } \\
40,74,70 / 76,95 / 66,5 \\
141,130 / 176,179,1\end{array}$ & $\begin{array}{l}\text { refer to Fig. } 1 \\
\text { individual org } \\
\text { e) }=\text { sum of } 1, \\
\text { yclohexane) }= \\
\text { s) = sum of her } \\
\\
\text { DDD, o, } p \text {-DDD } \\
\text { eners } 1,3,4 / 10 \\
56 / 60,91,84 / 8 \\
137,138,158,\end{array}$ & $\begin{array}{l}\text { ganisms ( } \\
2,4,5 \text {-tetı } \\
\text { sum of } \alpha \text { - } \\
\text { eptachlor, } \\
\\
0, p, p^{\prime} \text {-DD } \\
0,7,6,8 / 5 \\
89,101,99 \\
178 / 129,\end{array}$ & $\begin{array}{l}\text { (ind.) or pool } \\
\text { raClBz, } 1,2,3 \\
\text { - } \mathrm{HCH}, \beta-\mathrm{HC} \\
\text { heptachlor } € \\
\\
\mathrm{DE}, o, p-\mathrm{DDE} \\
5,19,18,17, \\
9,83,97,87 \\
175,187,1\end{array}$ & $\begin{array}{l}\text { Is of } 2 \text { or mol } \\
3,4 \text {-tetraClB } \\
\mathrm{CH} \text { and } \gamma \text {-HC } \\
\text { epoxide, cis- } \\
\\
p, p^{\prime} \text {-DDT a } \\
24 / 27,16 / 32 \\
85,136,110 \\
83,128,185\end{array}$ & $\begin{array}{l}\text { re individua } \\
\mathrm{Bz}, \text { pentaClB } \\
\mathrm{CH} \\
\text {--chlordane, } \\
\text { and } o, p \text {-DDT } \\
2,26,25,31, \\
0,82,151,144 \\
5,194,196 / 2\end{array}$ & $\begin{array}{l}\text { trans-chlorda } \\
\text { T } \\
28,33,22,45 \\
4 / 135,149,1 \\
203,189,208\end{array}$ & $\begin{array}{l}\text { me, cis-nonar } \\
46,52,49,4 \\
18,134,114,1 \\
3,195,207,1\end{array}$ & $\begin{array}{l}\text { achlor, trans- } \\
\\
17,48,44,42, \\
131,146,153 \\
194,205,20\end{array}$ & $\begin{array}{l}\text {-nonachlor } \\
\text { 41/71, 64, } \\
3,132,105 \\
06 \text { and 209 }\end{array}$ \\
\hline
\end{tabular}




\section{OC concentrations}

Concentrations (wet and lipid weight) of OCs in Arctic invertebrates varied by up to 2 orders of magnitude (Fig. 2, Table 2), with the greatest range in the benthic organisms and least variability in the pelagic organisms. In general, $\Sigma$ PCB had the highest and $\Sigma \mathrm{ClBz}$ the lowest concentrations, with the relative concentrations of the other $\Sigma \mathrm{OC}$ groups varying depending on the species.

The variables' lipid content, $\delta^{13} \mathrm{C}$ and $\delta^{15} \mathrm{~N}$ were found to significantly influence $\mathrm{OC}$ concentrations in marine invertebrates, although this varied with the SOC group, but the amount of variability explained by the GLM model was generally low. Lipid content (GLM, Type III $\mathrm{SS}, \mathrm{p}=0.07$ ) was not a significant variable; however, $\delta^{13} \mathrm{C}$ and $\delta^{15} \mathrm{~N}$ (GLM, Type III SS, p < 0.05) significantly influenced $\delta \mathrm{ClBz}$ concentrations, although the model examined less than $25 \%$ of the variability $\left(\mathrm{r}^{2}=0.247\right)$. $\delta \mathrm{HCH}, \delta \mathrm{DDT}$ and $\delta \mathrm{PCB}$ concentrations were significantly influenced by lipid content, $\delta^{13} \mathrm{C}$ and $\delta^{15} \mathrm{~N}$ (GLM, Type III SS, p < 0.05), but the amount of variability ( $\mathrm{r}^{2}$ values) examined by the GLM was $0.377,0.562$ and 0.308, respectively. Lipid content and $\delta^{15} \mathrm{~N}$ were found to significantly influence $\delta \mathrm{CHLOR}$ concentrations (GLM, Type III SS, p < 0.05), but $\delta^{13} \mathrm{C}$ did not (GLM, Type III SS, p = 0.22), with the GLM explaining $29 \%$ of the variability in $\delta$ CHLOR concentrations. Concentrations of OC groups increased with increasing $\delta^{15} \mathrm{~N}$, lipid content and less negative $\delta^{13} \mathrm{C}$.

After accounting for lipid content, $\delta^{15} \mathrm{~N}$ and $\delta^{13} \mathrm{C}$ significant differences between species (GLM, Type III SS, p < 0.05) remain for concentrations of all $5 \delta \mathrm{OC}$ groups. The inclusion of the variable species in the GLM made the variables $\delta^{13} \mathrm{C}$ and $\delta^{15} \mathrm{~N}$ non-significant regarding concentrations of $\delta \mathrm{ClBz}, \delta \mathrm{HCH}$, $\delta$ CHLOR and $\delta$ PCB (GLM, Type III SS, $\mathrm{p}>0.05)$. Lipid content, $\delta^{15} \mathrm{~N}, \delta^{13} \mathrm{C}$ and species were all significant variables influencing $\delta \mathrm{DDT}$ concentrations in the arctic marine invertebrates (GLM, Type III SS, p < 0.05).

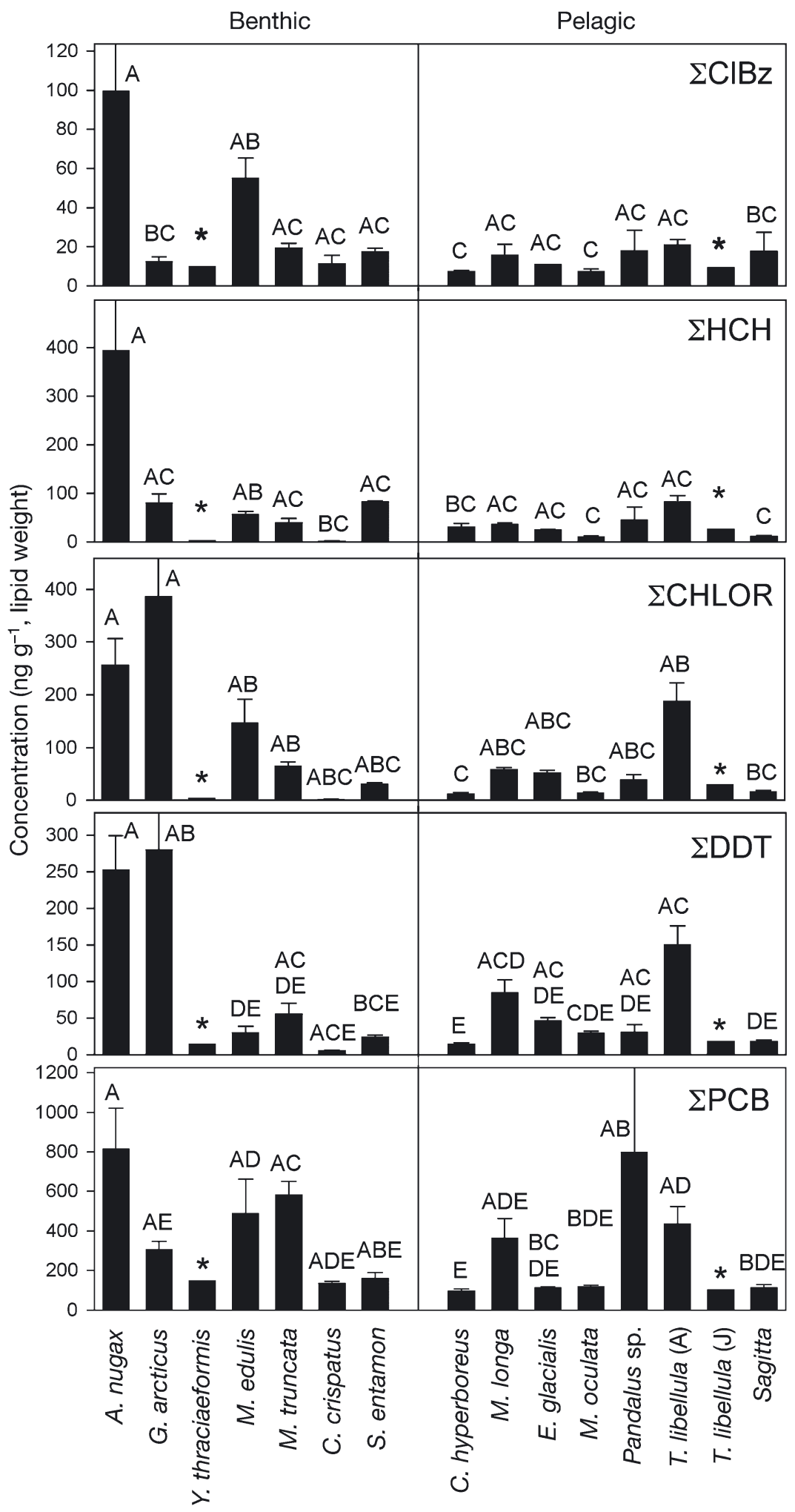

Fig. 2. Concentrations (ng $\mathrm{g}^{-1}$, lipid basis) of $\Sigma \mathrm{OC}$ groups in Arctic marine invertebrates. Bars are mean $\pm 1 \mathrm{SE}$, see Table 2 for sample numbers. Bars with the same letter do not differ significantly $(\mathrm{p}>0.05)$. Bars indicated by * were not compared statistically because only a single sample was analyzed. Benthic (box cores, baited traps, or by hand) and pelagic (zooplankton net tows) designations refer to collection method used 


\section{Relative proportions of OCs}

Relative proportions of $\Sigma \mathrm{OC}$ groups in the Arctic invertebrates are presented in Fig. 3. $\Sigma$ PCB makes up the largest proportion of OCs for all species except Gorgonocephalus arcticus, in which $\Sigma$ CHLOR makes up the highest percentage of OCs.

The most abundant individual OC analyte varied between species. Combining data for all species, the rank order (from highest to lowest) of individual OCs was PCB 31/28 (co-eluting congeners), $\alpha-H C H$, cis-chlordane, trans-nonachlor and $o, p^{\prime}$-DDT. Using data for the pelagic invertebrates produced a different ranking, with PCB 31/28 at the highest concentration followed by $\alpha-\mathrm{HCH}, p, p^{\prime}$-DDE, trans-nonachlor and PCB 66/95 (co-eluting congeners). In benthic invertebrates, $\alpha-\mathrm{HCH}$ was the most abundant OC analyte, followed by cis-chlordane, PCB 31/28, o, $p^{\prime}$-DDT and transnonachlor. A few species had notably different rank- ings. Metridia longa, a predator/suspension-feeding pelagic invertebrate, had a large number of PCB congeners as the most common compounds. Mya truncata, a suspension-feeding benthic clam collected in the harbor of Iqaluit, was dominated by higher chlorinated PCB congeners including PCBs 153, 138, 149, 180, 187 and 174 (the 6 compounds with the highest concentrations). Finally, $\alpha$ - and $\gamma$-HCH were the most common OCs in Saduria entamon, a detritivore/omnivore isopod collected in Barrow, AK, and was the only species that had $\gamma-\mathrm{HCH}$ among the most common OC compounds.

\section{DISCUSSION}

\section{Stable isotopes}

The designation of 'benthic' or 'pelagic' to describe the nature of the invertebrate species habitat based on collection method was in good agreement with the $\delta^{13} \mathrm{C}$ values measured. The $\delta^{13} \mathrm{C}$ values can be used to differentiate the source of carbon in aquatic organisms, as benthic-derived carbon is generally enriched in ${ }^{13} \mathrm{C}$, i.e. the $\delta^{13} \mathrm{C}$ values are higher than pelagic-derived carbon (France 1995). The exceptions were Pandalus sp. and Anonyx nugax. Pandalus sp. was collected by zooplankton net and designated as pelagic, but had a $\delta^{13} \mathrm{C}$ value that was more benthic. It should be cautioned that only 2 samples of Pandalus sp. were analyzed and that this species is associated with a benthic existence (Butler 1971). A. nugax was collected on the sediment surface with baited trap, but had a more pelagic $\delta^{13} \mathrm{C}$ signature. As a scavenging amphipod (Hargrave et al. 1992), this species would encounter and feed on dead pelagic organisms, which likely accounts for its more pelagic $\delta^{13} \mathrm{C}$ signature.

Benthic organisms examined fell into 2 general TLs. On the one hand, the suspension-feeding invertebrate Yoldia thraciaeformis, for which stable isotope values were available, was found to occupy the same TL (TL $=2$ ) as Calanus hyperboreus, classified as TL 2 based on its herbivorous diet. On the other hand, all the non-suspension-feeding invertebrates were more than 1 TL higher. Although only 1 sample of $Y$. thraciaeformis was analyzed for this study, a large study of the Northern Baffin Bay food web encompassing many samples found a similar $\delta^{15} \mathrm{~N}$ signature for
Fig. 3. Relative proportions of $\Sigma \mathrm{OC}$ groups ([ $\left.\Sigma \mathrm{OC}_{\mathrm{x}}\right]=\left[\Sigma \mathrm{OC}_{\mathrm{x}}\right] /[$ all $\mathrm{OC}$ groups]) in Arctic marine invertebrates. Benthic (box cores, baited traps, or by hand) and pelagic (zooplankton net tows) designations refer to collection method used 
suspension-feeding benthic invertebrates (Hobson et al. 2002). The relatively high derived TL of Anonyx nugax was not unexpected since this is scavenging benthic amphipod (Hargrave et al. 1992). These organisms can scavenge higher TL organisms that result in a pulse of high OC dietary input (Hargrave et al. 1992) and corresponding enrichment in $\delta^{15} \mathrm{~N}$ value. The higher TL of the detritus-feeding benthic invertebrates could be due to the scavenging of dead higher TL organisms in much the same way as A. nugax.

The derived trophic position of pelagic invertebrates was in general agreement with the feeding method suggested by the literature (Hobson et al. 2002). However, 1 exception was Themisto libellula, which, despite being a large predatory amphipod (Auell et al. 2002), was only 0.5 TLs above Calanus hyperboreus.

One potential problem with the comparison of stable isotope values among invertebrate species is that they were collected at different locations, seasons and year. Values of $\delta^{13} \mathrm{C}$ and $\delta^{15} \mathrm{~N}$ have been found to vary both spatial and temporal in zooplankton (Schell et al. 1998). However, all samples, with the exception of the Saduria entamon samples, were collected in the eastern Canadian Arctic. Stable isotope values in the basket starfish collected in northern and southern Baffin Bay were similar, suggesting that a comparison of species in these 2 regions is reasonable. $S$. entamon were collected in Alaska, and therefore comparisons with other species must be made with caution. Most species were collected between April and July in 1998 or 1999, and therefore season and year are likely to have a minor impact. The exceptions were $S$. entamon, collected in September 1999, and Mya truncate, collected in 1993; however, the latter were not analyzed for stable isotopes.

\section{OC concentrations}

A range of $\mathrm{OC}$ concentrations were found in the 14 Arctic invertebrate species examined in this work, although most were within 1 order of magnitude (Fig. 2, Table 2). More variability in OC levels among species was found in the benthic compared to the pelagic (zooplankton) invertebrates. This is likely due to the greater range of sizes, relative quantity of lipid reservoirs, and feeding strategies of the benthic invertebrates, in particular scavenging, which can result in higher OC concentrations. As expected due to their lower TLs, OC concentrations in the invertebrates from this study were lower than upper TL organisms of the Canadian Arctic, such as seabirds (Braune et al. 2001b) and marine mammals (Fisk et al. 2002). The highest concentrations of OCs were found in Anonyx nugax and Gorgonocephalus arcticus, with levels in the range of those of pelagic Arctic fish, arctic cod (Boreogadus saida), and of the low TL Arctic seabird dovekie (Alle alle; Fisk et al. 2001b). The OC concentrations in pelagic and suspension/detritus-feeding benthic invertebrates were among the lowest found in any biota in the world. However, a number of samples of the suspension feeder Mytilus edulis had very high $\Sigma$ PCB concentrations, but low concentrations of the other OCs, which is likely due a local source of contamination.

\section{Spatial trends of OCs and comparison to other studies}

There are limited data on OCs in marine invertebrates, particularly for zooplankton, with which to compare the results from this study. Additionally, seasonal changes in OCs have been observed in zoo-

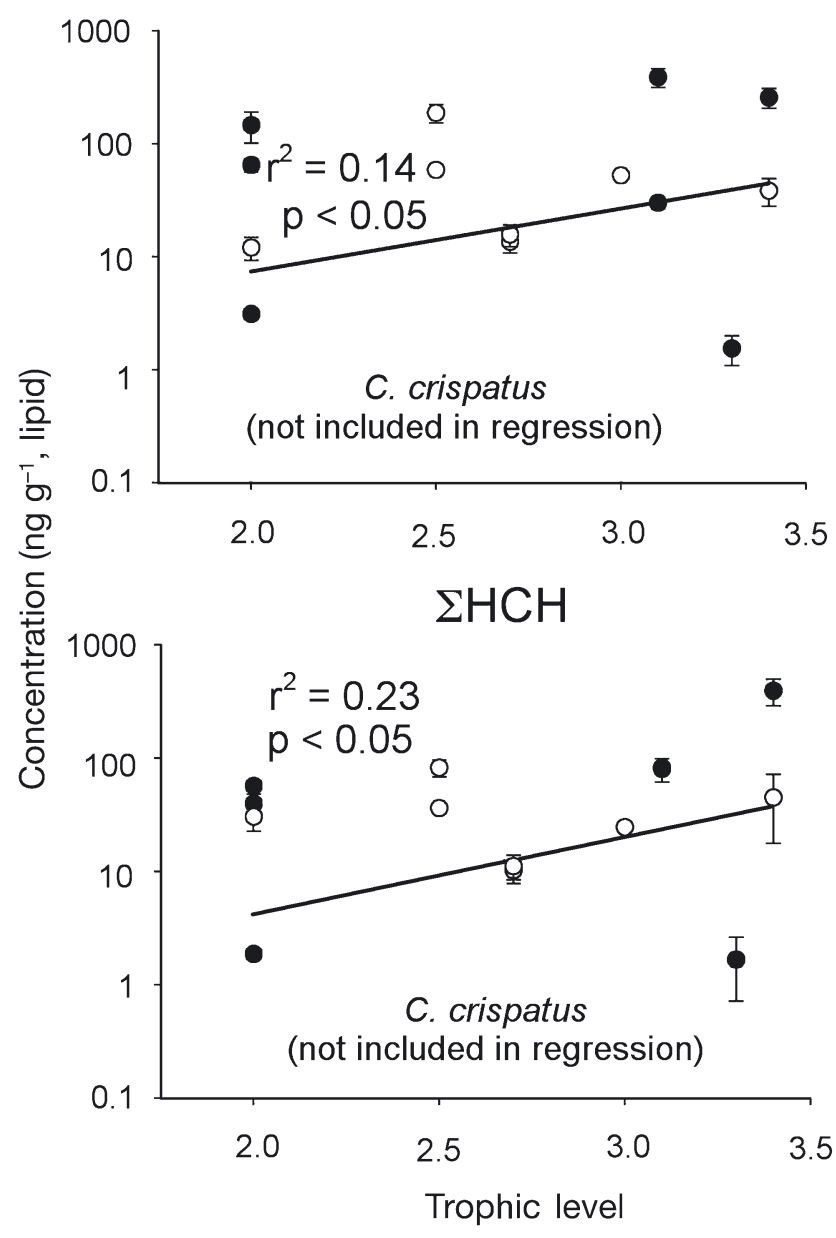

Fig. 4. Relationships between trophic level (based on $\delta^{15} \mathrm{~N}$ ) and natural log concentration $(\delta \mathrm{HCH}$ and $\delta \mathrm{CHLOR}$, lipid basis) in Arctic marine invertebrates. (•) Benthic invertebrates and (o) pelagic invertebrates. The line represents a linear regression through all data 
plankton (Hellou et al. 1997, Hargrave et al. 2000, Fisk et al. 2001a) that can confound efforts to compare different studies. The small size of most invertebrates, particularly zooplankters, means that they will likely reflect changes in water concentrations of OCs more quickly than larger higher TL organisms.

Circumpolar trends of OCs in marine zooplankton based on the results of this study and other recently published work are somewhat inconsistent and in part not in harmony with trends observed for upper TL organisms. For most OCs, the exception being HCHs, the highest concentrations in Arctic seabirds and marine mammals are observed in Russian or European Arctic waters and the lowest in Alaskan waters (de March et al. 1998, de Wit et al. 2003). OC concentrations determined in Calanoid copepod samples from Beaufort Sea (Hoekstra et al. 2002a) and Barents Sea (south of Svalbard) (Borgå et al. 2001, 2002a) were lower and higher, respectively, than those observed in this study. This is consistent with trends in higher TL organisms. However, OC concentrations in the Calanoid copepod (Calanus hyperboreus) from this study were greater than those measured in copepods from the east (Greenland Sea) and north of Svalbard (Barents Sea) (Borgå et al. 2001, 2002a). Moreover, levels of OCs were also higher in Northern Baffin Bay Themisto libellula compared with the same species collected east and north of Svalbard (Borgå et al. 2001). These spatial trends for C. hyperboreus and T. libellula held for $\delta O C$ groups or individual OCs and are not consistent with expectations for higher TL organisms. The exception was $\mathrm{HCH}_{\text {; }}$ the highest concentrations were observed in Alaska copepods consistent with circumpolar trends.

Adding further confusion to circumpolar trends in OC concentrations in Arctic marine zooplankton are the small amount of congener-specific data produced in the past. Levels of PCBs (measured as Aroclor 1254) in mixed zooplankton and Pandalus borealis collected near Svalbard in the early 1990s were 10 times higher, based on dry or lipid basis (Joiris et al. 1997), than those observed in the Baffin Bay samples from this study. These high levels observed by Joiris et al. (1997) could be explained in part by higher concentrations in the past (the samples were collected in the late 1980s) (de Wit et al. 2003).

Levels of OCs in zooplankton from more southerly oceans appear to be higher, but those in sub-Arctic waters are similar to levels found in Arctic zooplankton from this study. Weisbrod et al. (2000) reported concentrations (wet wt) of $\Sigma$ PCBs, $\Sigma$ DDT and $\Sigma$ CHLOR in calanoid copepods from the northeastern US seaboard that were 1 order of magnitude greater than those measured in the Calanus hyperboreus in this study, despite much lower lipid contents in the south- ern copepods. The exception was $\Sigma \mathrm{HCH}$, where concentrations on a lipid basis were very similar between the temperate and Arctic copepods. Similar levels in $\mathrm{HCH}$ concentrations are not unexpected because the higher vapor pressures of the $\mathrm{HCH}$ compared to the other OCs results in a net migration of $\mathrm{HCH}$ from temperate to Arctic regions (Wania \& Mackay 1999) and higher concentrations of $\mathrm{HCHs}$ in the Arctic Ocean compared with temperate oceans (Iwata et al. 1993).

OC concentrations (lipid basis) in calanoid copepods collected off the eastern coast of Newfoundland and Labrador in 1993 and 1994 (Ray et al. 1999) were similar to those observed in copepods from this study. The exception was $\Sigma$ PCB levels that were lower in the copepods from eastern Newfoundland and Labrador. Hellou et al. (1997) reported levels of chlordane and DDT components in Pandalus borealis eggs collected to the east of Newfoundland that were similar to those reported for Pandalus sp. whole body in this study. However, $\mathrm{PPCB}$ (based on Aroclor 1254) concentrations (4.3 $\mathrm{ng} \mathrm{g}^{-1}$ wet wt) in P. borealis eggs from Newfoundland were 1 order of magnitude lower than reported for Pandalus sp. in this study, even when reported on a lipid basis. The higher $\Sigma$ PCB concentrations observed in the zooplankton of Northern Baffin Bay compared to the north Atlantic Ocean is likely due in part to the greater number of PCB congeners measured in the current study, although concentrations (lipid basis) of PCB 153 were still approximately 2 times greater in the Baffin Bay Pandalus than in the north Atlantic Ocean.

Caution is needed when assessing spatial trends of OC concentrations in zooplankton. Concentrations of OCs in zooplankton may relate to when the samples were collected (Hargrave et al. 1992, Fisk et al. 2001a), seasonal changes in water concentrations of OCs (Hargrave et al. 2000), the source of water at these locations (Borgå et al. 2002b), and/or the differences in the analytical methods used (e.g. number of congeners measured) (de Wit et al. 2003). As small organisms, zooplankters would reflect subtle changes in OC concentrations in water that a large organism could not. The source of water to the Greenland Sea copepods would come predominantly from under the ice cap to the north, which would explain in part the lower concentration of OCs compared to the Baffin Bay and Barents Sea copepods. Additionally, the collection of the copepods from the east and north of Svalbard occurred in September and October, after the open water period. Hargrave et al. (2000) found that OC concentrations were highest in Arctic zooplankton during periods of ice cover. Levels, dynamics and circumpolar trends of $\mathrm{OC}$ concentrations in Arctic marine zooplankton warrant further study. 
There are also limited OC data for Arctic benthic invertebrates. Many of these data have been generated for harbors or human settlements that can have local contamination sources which influence observed levels of OCs (Bright et al. 1995, Hop et al. 2001). The majority of these data have been produced for edible clams and mussels.

The blue mussel Mytilus edulis is commonly used to monitor OCs in coastal areas around the northern hemisphere. It is also monitored at a number of locations in the Arctic. OCs were present at low levels in blue mussels from the 7 locations in Nunavik (northern Quebec) in this study, and with the exception of PCBs, were consistent among sampling locations (Table 2). Doidge et al. (1993) found low ng per g (wet wt) levels of PCBs and OC pesticides in a survey of blue mussels from 6 communities in Nunavik, similar to levels observed in this study. Cleeman et al. (2000) also reported similar levels of OCs in blue mussels from the west coast of Greenland. PCBs, DDT and HCBz levels in $M$. edulis from remote sites in southern Alaska were in the lower range of concentrations observed in the same species in this study (NOAA 2001, available at: ccmaserver.nos.noaa.gov/NSandT/AkPCB.html).

¿PCB concentrations in Mytilus edulis varied between and within locations in Nunavik, and for a number of samples had the highest $\Sigma$ PCB concentrations measured in this study (Table 2). Levels of $\delta$ PCBs were also relatively high in Mya truncata. $M$. edulis and $M$. truncata samples were all collected within 1 or $2 \mathrm{~km}$ from the harbors of each community, in mussel beds traditionally harvested by each community. While not within the harbor, these sites may have been influenced by waste emissions from each community. These results provide further evidence that Arctic communities can be a source of PCBs, but not pesticides, resulting in higher PCB concentrations in local marine benthic invertebrates. The influence of communities on PCB levels in local marine invertebrates has been documented in Canada (Bright et al. 1995) and Svalbard (Hop et al. 2001). The greater sorption of PCBs to flocculating particles is due to their high hydrophobicity compared to most other OCs, and the fact that mussels consume these particles may also account for higher amounts of PCBs.

OC data generated from benthic invertebrates collected in remote areas of Arctic Canada and western Greenland are in general agreement with levels found in this study, although there are very limited data produced in recent years. Concentrations of $\Sigma$ PCB in mussels from Queen Maud Gulf were approximately $1.5 \mathrm{ng}$ $\mathrm{g}^{-1}$ wet wt (Bright et al. 1995), and in clams from southern Hudson Bay were $1.1 \mathrm{ng} \mathrm{g}^{-1}$ wet wt (Cameron \& Weis 1993), both similar to levels observed in Yoldia thraciaeformis in Northern Baffin Bay. Cleeman et al.
(2000) reported $\Sigma$ PCB concentrations in $M$. edulis collected between 1994 and 1995 from western Greenland (south of the Baffin Bay samples analyzed in this study) that were approximately half those observed in $Y$. thraciaeformis in Northern Baffin Bay. However, only 10 congeners were quantified in the aforementioned study, which likely accounts for this difference. Concentrations of $\Sigma \mathrm{HCH}, \Sigma \mathrm{DDT}$ and trans-nonachlor were similar between the 2 studies. Levels of OCs in Anonyx nugax samples from Barrow Strait prior to 1994 (B. T. Hargrave unpubl. data, in de March et al. 1998) were very similar to concentrations observed in A. nugax from the present study.

\section{Relative proportions}

PCBs were the most common OC measured in the invertebrates, but relative proportions of $\Sigma O C$ groups varied considerably among species (Fig. 3). Similar to observed concentrations, there was more variability in the relative proportions of $\mathrm{OC}$ groups in the benthic invertebrates.

Relative proportions of OCs in the pelagic invertebrates varied slightly among species and to a greater extent in Pandalus sp. The high proportion of PCB in Pandalus sp. may be related to its more benthic nature (see above) and its higher TL (Table 1). The lesser variation between pelagic species is not easily explained, and does not appear to be related to body size or trophic position. For example, Metridia longa and Mysis oculata had nearly identical relative proportions, but are the smallest and second largest zooplankton, respectively, in this study. These relative proportions in this study are similar to those observed in pelagic copepods and amphipods in the Barents Sea, but with a lower proportion of PCBs (Borgå et al. 2001, 2002a), which is likely due to smaller number of PCB congeners measured in the Borgå et al. studies.

PCBs accounted for 60 to $80 \%$ of the OCs measured in the suspension-feeding benthic invertebrates (Mya truncata, Mytilus edulis and Yoldia thraciaeformis) and the detritus-feeding starfish (Ctenodiscus crispatus), and with the exception of pelagic Pandalus sp., this was the highest percentage found in this study. PCBs are the most hydrophobic group of OCs measured in this study and are likely partitioning to particulate matter and being exported to the benthos at a greater rate than the other OCs. This is maybe influencing the relative proportions OCs in the $Y$. thraciaeformis and C. crispatus, which were collected at depths of more than $300 \mathrm{~m}$. M. truncata and $M$. edulis were collected in shallow water by hand, but near communities and harbors. As discussed above, these locations may be sources of PCBs; the high relative proportions of PCBs 
in these species only strengthen this argument. Further, $M$. truncata is dominated by higher chlorinated PCBs, those with 6 to 8 chlorines, which in such a low TL invertebrate, can only be explained by a local source.

Sampling region can also play a role in relative proportions of contaminants. Although most samples were collected in the eastern Canadian Arctic, Saduria entamon were collected to the west in Alaskan waters. This species had the greatest relative proportions of $\mathrm{HCH}$ of any species in this study. $\mathrm{HCH}$ concentrations are generally highest in the Alaskan and western Canadian Arctic due to recent use in Asia and long-range transport of $\mathrm{HCH}$ to this region (de Wit et al. 2003).

\section{Factors influencing OC levels}

This study found that the variables lipid content, $\delta^{13} \mathrm{C}$ and $\delta^{15} \mathrm{~N}$ influenced OC concentrations, although this varied with the OC group. However, the amount of variability examined was generally low $\left(\mathrm{r}^{2}\right.$ ranged from 0.25 to 0.38$)$ with the exception of $\delta \mathrm{DDT}\left(\mathrm{r}^{2}=0.56\right)$, and differences in $\mathrm{OC}$ concentrations between species remained after accounting for these variables.

In general, OC concentrations increase with increasing lipid content, $\delta^{15} \mathrm{~N}$ and $\delta^{13} \mathrm{C}$. Lipids have been found to be an important variable in other studies of OCs in zooplankton (Hargrave et al. 2000). The relationship between $\mathrm{OC}$ concentrations and $\delta^{13} \mathrm{C}$ implies that benthic organisms have higher OC concentrations. Derived TL based on $\delta^{15} \mathrm{~N}$ and subsequent dietary accumulation influence observed OC concentrations in Arctic marine invertebrates, but not to the extent that they do in food webs that incorporate a wider range of TLs. Strong relationships between OC concentrations (l.w.) and $\delta^{15} \mathrm{~N}$ values (Hop et al. 2002) or TL based on $\delta^{15} \mathrm{~N}$ values (Fisk et al. 2001b) have been observed for Arctic marine food webs that include zooplankton, fish, seabirds and marine mammals. Borgå et al. $(2002 a, b)$ found that diet accounted for most of the variability in zooplankton and amphipods collected near Svalbard, with concentrations greater in carnivores.

TL of an organism based on $\delta^{15} \mathrm{~N}$ values is an integrated average over some period prior to sampling which depends on the turnover rate of nitrogen in the tissue which is sampled (Peterson \& Fry 1987); in this paper, the whole animal. If the organism consistently feeds at $1 \mathrm{TL}$, then it is likely that correlations with persistent organic contaminant concentrations will be well-behaved, and fit within the context of whole food web magnification relationships. However, if there are changes in trophic status, e.g. due to catabolism or change in prey during certain seasons, the relationship between $\delta^{15} \mathrm{~N}$ values and contaminant concentrations may break down. Whether or not this is the case depends on: (1) the relative importance of food and water in contaminant uptake; (2) changes in the ratio of contaminant concentration $/ \delta^{15} \mathrm{~N}$ over time; and (3) the rate of turnover (clearance) of the contaminant relative to that of nitrogen. If uptake from water is important, which may be the case for some of the less hydrophobic contaminants (Thomann 1989, Russell et al. 1999), then TL is of less consequence. It is largely the lipid content which will determine degree of bioconcentration (Barron 1990). If food is the most important contaminant source, which is likely the case for hydrophobic contaminants (Harding et al. 1981, Russel et al. 1999), TL becomes important. Consideration must then be given as to whether the contaminant is turned over at a similar or different rate to that of nitrogen if the isotopic signature of nitrogen in the organism is changing because of diet changes, fasting, reproduction, or the contaminant concentration in the diet is changing without a corresponding change in $\delta^{15} \mathrm{~N}$. If contaminant clearance is very slow compared to nitrogen turnover rates, a change in trophic status will likely result in a disparity between observed $\mathrm{OC}$ and $\delta^{15} \mathrm{~N}$ values when compared to other organisms. This is likely to be the case for the more hydrophobic chemicals and has been observed for scavenging seabirds (Fisk et al. 2001b). If contaminant clearance rate is similar to, or faster than that of nitrogen turnover rate, then the 2 will be in lock step, and the relationship between contaminant concentration and TL is maintained-provided that the diet itself has a stable contaminant concentration versus TL relationship.

A good indication of the complexity of this issue for marine plankton is the seasonal changes in contaminant concentration and TL of Calanus hyperboreus in Northern Baffin Bay (Fisk et al. 2001a). Over a 3 mo period (May to July), $\delta^{15} \mathrm{~N}$ decreased by ca. $2 \%$, more than $0.5 \mathrm{TL}$, while concentrations of PCBs remained stable, and concentrations of the less hydrophobic contaminant, $\mathrm{HCH}$, actually increased (along with lipid concentrations). In this case, seawater concentrations were likely the deciding factor, rather than TL. Nevertheless, organisms that prey on C. hyperboreus will be exposed to significantly different ratios of contaminant concentration $/ \delta^{15} \mathrm{~N}$ in April compared to August. These perturbations at the bottom of food webs are carried through to higher TLs, resulting in significant noise in contaminant concentration versus TL relationships, especially at lower TLs. Trophic or food web magnification factors based on the slope of log concentration versus TL appear to be relatively unaffected by this noise if there are sufficient numbers of data and the span is over 3 or more TLs. 


\section{CONCLUSIONS}

The results of this research have provided further evidence that stable isotopes can identify the habitat and trophic position of Arctic marine invertebrates. OC concentrations in invertebrates were low relative to similar species in temperate waters and higher TL Arctic organisms. PCBs were the predominant OC group found in most species, and lower chlorinated $\mathrm{PCB}$ congeners and $\mathrm{HCH}$ isomers were the most common individual $\mathrm{OC}$ compounds measured. Lipid content, $\delta^{15} \mathrm{~N}$ and $\delta^{13} \mathrm{C}$ were all found to be significant variables influencing OC concentration, but differences among species remained after accounting for these variables. Evidence of local contaminant sources and its influence on $\mathrm{OC}$ concentrations in invertebrates was found. Scavenging, high TL, high lipid content, sampling location and local point sources can all contribute to higher OC concentrations in Arctic marine invertebrates.

Acknowledgements. Funding for this project was provided in part by a Natural Science and Engineering Research Council (NSERC) Network grant on the Northwater Polynya, the Canadian Wildlife Service, the Polar Continental Shelf Project, the Co-operative Institute for Arctic Research (University of Alaska, Fairbanks) and the Northern Contaminants Program administered by the Department of Indian and Northern Affairs. The authors would like to thank the many scientists of the NOW project, especially N. Karnovsky, M. Holst, I. Stirling, D. Andriashek, N. Lunn, G. Hunt, M. Fortier, M. Ringette and L. Fortier. Collection of the Alaskan invertebrate samples was supported by the Department of Wildlife Management (Barrow, Alaska), T. O'Hara, T. Albert, C. Brower, L. Dela Rosa, B. Akootckok, A. Brower and D. Vinas. L. Dehn and D. Norton assisted with sample collection at Barrow. We thank P. Healy for assistance with sample preparation and G. Parry for stable isotope analyses. We thank the HTA (Hunters and Trappers Association) of Grise Fjord for granting us permission to collect samples in their area. This project would not have been possible without the dedicated and skillful assistance of the 'Pierre Radisson' Coast Guard captains and crew. We thank F. Murphy, J. Lampe and F. Andersen (Labrador Inuit Association, NF) for collection of mussels in Nain and Makkovik, and the HTAs of Quaqtaq, Kuujjaaq, Kangipsujuaq and Kangiqsualujjuaq in Nunavik (northern Quebec) for providing mussels from their communities.

\section{LITERATURE CITED}

Auell H, Harjesl M, da Rochal R, Stübingl D, Hagenl W (2002) Lipid biomarkers indicate different ecological niches and trophic relationships of the Arctic hyperiid amphipods Themisto abyssorum and T. libellula. Polar Biol 25:374-383

Barron MG (1990) Bioconcentration. Environ Sci Technol 24: $1612-1618$

Bidleman TF, Jantunen LMM, Helm PA, Brorstrom-Lunden E, Juntto S (2002) Chlordane enantiomers and temporal trends of chlordane isomers in Arctic air. Environ Sci Technol 36:539-544
Borgå K, Gabrielsen GW, Skaare JU (2001) Biomagnification of organochlorines along a Barents Sea food chain. Environ Pollut 113:187-198

Borgå K, Gabrielsen GW, Skaare JU (2002a) Differences in contamination load between pelagic and sympagic invertebrates in the Arctic marginal ice zone: influence of habitat, diet and geography. Mar Ecol Prog Ser 235:157-169

Borgå K, Poltermann M, Polder A, Pavlova O, Gulliksen B, Gabrielsen GW, Skaare JU (2002b) Influence of diet and sea ice drift on organochlorine bioaccumulation in Arctic ice-associated amphipods. Environ Pollut 117:47-60

Borgå K, Gulliksen B, Gabrielsen GW, Skaare JU (2002c) Size-related bioaccumulation and between-year variation of organochlorines in ice-associated amphipods from the Arctic Ocean. Chemosphere 46:1383-1392

Braune B, Bidleman T, Fisk A, Muir D (2001a) Assessment of spatial and temporal trends of $\mathrm{HCH}$ isomers in the Arctic environment. In: Kalhok S (ed) Synopsis of research conducted under the 2000-2001 Northern Contaminants Program. Indian and Northern Affairs Canada, Ottawa, p 152-159

Braune BM, Donaldson GM, Hobson KA (2001b) Contaminant residues in seabird eggs from the Canadian Arctic. I. Temporal trends 1975-1998. Environ Pollut 114:39-54

Bright DA, Dushenko WT, Grundy SL, Reimer KJ (1995) Effects of local and distant contaminant sources: polychlorinated biphenyls and other organochlorines in bottomdwelling animals from an Arctic estuary. Sci Total Environ 160/161:265-283

Butler TH (1971) A review of the biology of the pink shrimp (Pandalus borealis). Can Fish Rep 17:17-24

Cameron M, Weis IM (1993) Organochlorine contaminants in the country food diet of the Belcher Island Inuit, Northwest Territories, Canada. Arctic 46:42-48

Cleeman M, Riget F, Paulson GB, Klungsoyr J, Dietz R (2000) Organochlorines in Greenland marine fish, mussels and sediments. Sci Total Environ 245:87-102

de March BGE, de Wit CA, Muir DCG, Braune BG and 5 others (1998) Persistent organic pollutants. Arctic Monitoring and Assessment Program, Oslo

de Wit CA, Fisk A, Hobbs K, Muir D, Kallenborn R, Krahn M, Norstrom R, Skaare J (2003) Persistent organic pollutants, AMAP II Assessment Report. Arctic Monitoring and Assessment Program, Oslo

Doidge DW, Kaminski G, Mesher C (1993) Blue mussels (Mytilus edulis) in Nunavik: distribution demography and commercial potential. Report to Fisheries and Aquaculture Testing and Experimentation Program of the Department of Fisheries and Oceans, Kuujjuaq, PQ

Fisk AT, Stern GA, Hobson KA, Strachan WJ, Loewen MD, Norstrom RJ (2001a) Persistent organic pollutants (POPs) in a small, herbivorous, Arctic marine zooplankton (Calanus hyperboreus): trends from April to July and the influence of lipids and trophic transfer. Mar Pollut Bull 43: 93-101

Fisk AT, Hobson KA, Norstrom RJ (2001b) Influence of chemical and biological factors on trophic transfer of persistent organic pollutants in the Northwater Polynya marine food web. Environ Sci Technol 35:732-738

Fisk AT, Holst M, Hobson KA, Duffe J, Moisey J, Norstrom RJ (2002) Comparison of persistent organic pollutants (POPs) and enantiomeric signatures of chiral pollutants in ringed seals collected on the east and west side of the Northwater Polynya. Arch Environ Contam Toxicol 42:118-126

France RL (1995) Carbon-13 enrichment in benthic compared to planktonic algae: food web implications. Mar Ecol Prog Ser 124:307-312 
Harding GC, Vass WP, Drinkwater KF (1981) Importance of feeding, direct uptake from seawater, and transfer from generation to generation in the accumulation of an organochlorine $\left(p, p^{\prime}\right.$-DDT) by the marine planktonic copepod Calanus finmarchicus. Can J Fish Aquat Sci 38:101-119

Hargrave BT, Harding GC, Vass WP, Erickson PE, Fowler BR, Scott V (1992) Organochlorine pesticides and polychlorinated biphenyls in the Arctic Ocean food web. Arch Environ Contam Toxicol 22:41-54

Hargrave BT, Phillips GA, Vass WP, Bruecker P, Welch HE, Siferd TD (2000) Seasonality in bioaccumulation of organochlorines in lower trophic level Arctic marine biota. Environ Sci Technol 34:980-987

Hellou J, Parsons D, Mercer G (1997) Organochlorine contaminants in the northern shrimp, Pandalus borealis, collected from the Northwest Atlantic. Mar Environ Res 44:99-113

Hobson KA, Welch HE (1992) Determination of trophic relationships within a high Arctic marine food web using stable-isotope analysis. Mar Ecol Prog Ser 84:9-18

Hobson KA, Ambrose WG Jr, Renaud PE (1995) Sources of primary production, benthic-pelagic coupling, and trophic relationships within the Northeast Water Polynya: insights from $\delta^{13} \mathrm{C}$ and $\delta^{15} \mathrm{~N}$ analysis. Mar Ecol Prog Ser 128:1-10

Hobson KA, Fisk AT, Karnovsky N, Holst M, Gagnon JM, Fortier M (2002) A stable isotope $\left(\delta^{13} \mathrm{C}, \delta^{15} \mathrm{~N}\right)$ model for the North Water Polynya foodweb: implications for evaluating trophodynamics and the flow of energy and contaminants. Deep-Sea Res II 49:5131-5150

Hoekstra PF, O'Hara TM, Teixeira C, Backus S, Fisk AT, Muir DCG (2002a) Spatial trends and bioaccumulation of organochlorine pollutants in marine zooplankton from the Alaskan and Canadian Arctic. Environ Toxicol Chem 21: 575-583

Hoekstra PF, Dehn LA, George JC, Muir DCG, Solomon KM, O'Hara TM (2002b) Trophic ecology of bowhead whales (Balaena mysticetus) compared with that of other Arctic marine biota as interpreted from carbon-, nitrogen-, and sulfur-isotope signatures. Can J Zool 80:223-231

Hop H, Sagerup K, Schlabach M, Gabrielsen GW (2001) Persistent organic pollutants in marine macro-benthos near urban settlements in Svalbard; Longyearbyen, Pyramiden, Barentsburg, and Ny-Alesund. Norwegian Polar Institute Report No. 8, Tromsø

Hop H, Borgå K, Gabrielsen GW, Kleivane L, Skaare JU (2002) Food web magnification of persistent organic pollutants in poikilotherms and homeotherms from the Barents Sea. Environ Sci Technol 36:2589-2597

Iwata H, Tanabe S, Sakai N, Tatsukawa R (1993) Distribution of persistent organochlorines in the oceanic air and surface seawater and the role of ocean on their global transport and fate. Environ Sci Technol 27:1080-1098

Joiris CR, Laroussi Moatemri N, Holsbeek L (1997) Mercury and polychlorinated biphenyls in zooplankton and shrimp from the Barents Sea and the Spitsbergen Area. Bull Environ Contam Toxicol 59:472-478

Khlebovich VV (1997) Selection and criteria for biological indicator species for Arctic monitoring. Mar Pollut Bull 35: 381-383

Editorial responsibility: Otto Kinne (Editor), Oldendorf/Luhe, Germany
Lawson JW, Hobson KA (2000) Diet of harp seals (Pagophilus groenlandicus) in nearshore-northeast Newfoundland: inferences from stable-carbon $\left(\delta^{13} \mathrm{C}\right)$ and nitrogen $\left(\delta^{15} \mathrm{~N}\right)$ isotope analysis. Mar Mamm Sci 16:578-591

Macdonald RW, Harner T, Fyfe J, Loeng H, Weingartner T (2003) AMAP assessment 2002: the influence of global change on contaminant pathways to, within, and from the Arctic. Arctic Monitoring and Assessment Programme, Oslo

Michener RH, Schell DM (1994) Stable isotope ratios as tracers in marine aquatic food webs. In: Lajtha $\mathrm{K}$, Michener RH (eds) Stable isotopes in ecology and environmental science. Blackwell Scientific Publications, London, p 138-157

Muir DCG, Segstro MD, Hobson KA, Ford CA, Stewart REA, Olpinski S (1995) Can elevated levels of PCBs and organochlorine pesticides in walrus blubber from eastern Hudson Bay (Canada) be explained by consumption of seals? Environ Pollut 90:335-348

Peterson BJ, Fry B (1987) Stable isotopes in ecosystem studies. Annu Rev Ecol Syst 18:293-320

Ray S, Paranjape MA, Koenig B, Paterson G, Metcalfe T, Metcalfe C (1999) Polychlorinated biphenyls and other organochlorine compounds in marine zooplankton off the east coast of Newfoundland, Canada. Mar Environ Res 47:103-116

Russell RW, Gobas FAPC, Haffner GD (1999) Role of chemical and ecological factors in trophic transfer of organic chemicals in aquatic food webs. Environ Toxicol Chem 18: 1250-1257

Schell DM, Barneet BA, Vinette KA (1998) Carbon and nitrogen isotope ratios in zooplankton of the Bering, Chukchi and Beaufort seas. Mar Ecol Prog Ser 162:11-23

Stokker YD (2000) Northern contaminant program interlaboratory quality assurance program for 1999-2000. In: Kalhok S (ed) Synopsis of research conducted under the 1999-2000 Northern Contaminants Program. Indian and Northern Affairs Canada, Ottawa, p 329-339

Stokker YD (2001) Northern contaminant program interlaboratory quality assurance program for 2000-2001. In: Kalhok S (ed) Synopsis of research conducted under the 1999-2000 Northern Contaminants Program. Indian and Northern Affairs Canada, Ottawa, p 364-371

Thomann RV (1989) Bioaccumulation model of organic chemical distribution in aquatic food chains. Environ Sci Technol 23:699-707

Valiela I (1995) Marine ecological processes, 2nd edn. Springer-Verlag, New York

Wallberg P, Andersson A (2000) Transfer of carbon and a polychlorinated biphenyl through the pelagic microbial food web in a coastal ecosystem. Environ Toxicol Chem 19:827-835

Wania F, Mackay D (1999) Global chemical fate of $\delta$-hexachlorocyclohexane. 2. Use of a global distribution model for mass balancing, source apportionment, and trend prediction. Environ Toxicol Chem 18:1400-1407

Weisbord AV, Shea D, Moore MJ, Stegeman JJ (2000) Organochlorine exposure and bioaccumulation in the endangered Northwest right whale (Eubalaena glacialis) population. Environ Toxicol Chem 19:654-666

Submitted: November 11, 2002; Accepted: August 24, 2003 Proofs received from author(s): October 23, 2003 